\title{
CORAK-CORAK PSIKOLOGI ISLAM
}

\author{
Rahmat Aziz
}

\begin{abstract}
.
It is the fact, that the thought of western psychology has expand speedy, and adopted by many scholars, include us. However, it does not mean that there is no flawed in western psychology. For instance, Freud's psychoanalysis is considered over simplified and cannot explain some problems such as fitrah in Islam, John Lock's behaviorist did not admit human intrinsic potencies which empirically cannot be denied, in addition, humanistic of Maslow have ignored factor and the role of God in the human life.

Islamic psychology comes into being to respond for the lack of western psychology theories. There are two ways in developing Islamic psychology; praxis and theoretic. Praxis method means developing Islamic psychology based on what have been developed by western psychology then we filter it and search the legitimacy for it; meanwhile, theoretic method means developing Islamic psychology based on the teaching and resources of Islamic knowledge itself.
\end{abstract}

Keyword: Psychology, Western, and Islam.

Ada perbedaan cukup tajam antara Ziauddin Sardar dan Ismail Raji alFaruqi tentang gerakan Islamisasi ilmu. Menurut Sardar, islamisasi harus berangkat dari pandangan dunia (world view) yang Islami dan paradigma keilmuannya, ${ }^{1}$ sedang bagi Faruqi gerakan Islamisasi dimulai dari adanya kritik terhadap ilmu-ilmu modern dengan menggunakan Islam sebagai analisisnya, setelah itu baru diadakan sintesis. ${ }^{2}$ Kedua pandangan diatas mempunyai kelebihan dan kekurangan tersendiri. Pandangan pertama sangat ideal dalam tatanan teoritis tapi lemah dalam aplikasi karena memerlukan waktu yang sangat lama, sedangkan pandangan kedua unggul dalam aplikasi karena bisa langsung menjawab persoalan-persoalan umat saat ini tapi lemah dalam dataran teoritis karena bisa terjebak dalam gerakan westernisasi ilmu.

Menurut Djamaluddin Ancok \& Fuad Nashori, dari kedua pandangan diatas diperkirakan pandangan kedualah yang akan memenangkan pertarungan. ${ }^{3}$ Hal ini bisa terlihat dari banyaknya kalangan ilmuwan yang sudah melakukan seperti saran Faruqi. Salah satu diantaranya adalah kalangan ilmuwan psikologi. Para ilmuwan psikologi saat ini merasakan adanya beberapa kelemahan mendasar dari teori-teori psikologi modern sehingga perlu mengajukan satu alternatif psikologi. inilah yang kemudian memuncul alternatif psikologi Islami.

\section{Kritik Terhadap Psikologi Modern}

Kritik merupakan bagian dari sikap ilmiah yang melekat pada diri ilmuwan. Ilmuwan sebagai penemu, penguasa, pengembang, pengendali, dan peramal sains, tidak boleh tidak harus membuka diri untuk di kritisi sekaligus mengkritisi. Ilmuwan sebenarnya sudah kehilangan makna keilmuwannya jika sudah tidak memiliki semangat mengkritisi atau tidak tahan dikritisi. Begitu juga 
teori sebuah ilmu, termasuk teori psikologi modern, akan kehilangan dinamikanya ketika menutup diri dari kritikan.

Dalam sejarah perkembangan psikologi terlihat bahwa lahirnya teori psikologi yang kemudian disusul teori psikologi yang lain adalah karena semangat mengkritik, yaitu mengkritik teori psikologi yang lama untuk kemudian membangun teori psikologi yang baru. Ini sesuai dengan pendapat Kuhn bahwa gelombang revolusi ilmu pengetahuan selalu ditandai oleh pergeseran dan penggantian dominasi paradigma ilmu yang berlaku. ${ }^{4}$ Karena itu, menjadi suatu hal yang sangat urgen untuk segera melakukan kritik terhadap teori-teori psikologi modern kemudian memberikan solusi alternatif.

Kerlinger menyatakan bahwa salah satu fungsi sebuah teori adalah sebagai penjelas. ${ }^{5}$ Artinya teori tersebut diharapkan mampu memberikan penjelasan terhadap suatu fenomena yang ada, baik berupa hubungan sebab-akibat (kausalitas) atau hubungan yang non sebab-akibat (nir-kausalitas). Suatu teori akan runtuh ketika ia tidak mampu lagi memberikan penjelasan terhadap fenomena yang ada. Demikian juga dalam bidang psikologi. Saat ini banyak fenomena yang tidak mampu lagi dijelaskan dari sudut pandang teori psikologi modern. Untuk menjawab kenyataan diatas, keberadaan teori psikologi yang baru menjadi mutlak diperlukan.

Berbicara tentang psikologi modern, setidaknya ada tiga aliran besar yang biasa dijadikan rujukan. ${ }^{6}$ Semua aliran itu lahir di Barat, sehingga menurut Nashori, pola pikir (mode of thought) yang digunakannya juga adalah masyarakat Barat. $^{7}$ Jika teori-teori tersebut digunakan untuk menganalisis masyarakat nonBarat (Islam), adanya bias-bias menjadi tidak terelakkan. Kritis atas kelemahan psikologi Barat seprti itu sudah banyak disampaikan, baik oleh kalangan mereka sendiri seperti Ruth Benedict, ${ }^{8}$ atau dari kalangan lain.

\section{Kritik Atas Aliran Psikoanalisis.}

Aliran psikoanalisis dipelopori oleh Sigmund Freud. ${ }^{9}$ Menurutnya, kehidupan manusia ditentukan oleh adanya dorongan-dorongan id (ego) yang bertujuan untuk memuaskan kesenangan (the principle of pleasure). Ego ini sangat ditentukan oleh masa lalunya, khususnya ketika masih balita, sedang hati nurani (super ego) muncul karena adanya interaksi individu dengan lingkungan sosialnya.

Teori Freud tentang dorongan id (libido sexual) termasuk salah satu teori yang mendapat kritik keras karena dianggap terlalu menyederhanakan kompleksitas hidup seseorang. Apalagi jika dilihat dari perspektif Islam, teori ini tidak akan mampu menjelaskan kebutuhan manusia untuk beragama yang dalam ajaran Islam diyakini bahwa manusia punya kecenderungan untuk beragama (fithrah) sebagaimana dijelaskan dalam hadits Nabi, Setiap manusia yang lahir ke dunia membawa bekal fithrah (sikap bertauhid), (HR. Bukhari).

Pandangan Freud yang menyatakan bahwa manusia sangat dipengaruhi masa lalunya juga perlu dikritik. Menurut Freud, untuk memahami perilaku seseorang pada saat ini, kita harus merujuk kehidupannya di masa kecil. Pendapat ini mempunyai kelemahan yang sangat mendasar karena hidup seseorang berarti menjadi determinist yang akhirnya meyebabkan fatalism. Jika kehidupan masa 
kecilnya tidak baik, maka masa depannya tidak akan jauh berbeda, sehingga seolah-olah tidak ada lagi harapan pada manusia untuk berkembang kearah yang lebih baik. Islam sangat berbeda dengan pandangan diatas. Meski Islam menekankan arti pentingnya masa kanak-kanak, tapi itu bukan segalanya karena masih ada proses yang terus berlangsung untuk menuju kesempurnaan hidup. Islam adalah suatu agama yang memberikan kebebasan pada manusia untuk berbuat sesuai dengan kehendaknya, dengan catatan bahwa semua itu akan diminta pertanggung jawaban.

\section{Kritik Atas Aliran Behavioristik.}

Tokoh aliran behavioris diantaranya adalah Watson, Pavlov, Skinner dan Thorndike. ${ }^{10}$ Aliran ini dipengaruhi oleh filsafat empiris yang disponsori oleh John Lock. Aliran ini memandang bahwa manusia dilahirkan bagaikan sebuah kertas putih yang tidak ada tulisan apapun. lingkunganlah yang mengisi bentuk dan corak dari kertas tersebut. Berdasarkan pandangan ini kaum behavioris berpendapat bahwa manusia dalam kehidupannya akan berkembang sesuai dengan stimulus yang diterima dari lingkungannya.

Kritik yang diajukan atas aliran ini adalah hilangnya potensi manusia yang ada pada tiap individu. Kenyataanya, manusia lahir dengan potensi ciri khasnya sendiri yang berbeda antara yang satu dengan yang lain, dan inilah yang dilupakan oleh kaum behavioris. Kritik lain adalah kecenderungannya untuk mereduksi nilai-nilai kemanusiaan. Hal ini terlihat dari cara kaum behavioris memperlakukan seorang anak. Mereka beranggapan bahwa seorang anak akan berperilaku (memberikan respon) sesuai dengan stimulus yang diberikan. Ini berarti manusia dianggap sebagai sebuah mesin sehingga teorinya bersifat mekanistis.

\section{Kritik Atas Aliran Humanistik}

Aliran humanistik muncul karena adanya ketidak percayaan terhadap kaum psikoanalisis dan behavioristik. Tokoh yang dianggap sebagai figur aliran ini adalah Maslow, Rogers, dan lain-lain. Dalam beberapa hal, aliran ini tampak sesuai dengan ajaran Islam karena sangat apresiatif terhadap keunikan pribadi, penghayatan subjektifitas, adanya rasa tanggung jawab dan yang paling penting adanya kemampuan pada manusia untuk melakukan aktualisasi diri. Salah satu aliran humanistik yang dikembangkan Victor Frankl dianggap sebagai aliran yang sesuai dengan ajaran Islam. ${ }^{11}$

Namun, itu tidak berarti bahwa aliran ini lepas dari kritik. Kelemahan utama aliran ini justeru terletak pada pandangannya yang terlalu optimistik terhadap manusia itu sendiri yang keadaan ini pada gilirannya akan menyebabkan manusia dianggap menjadi penentu terhadap kehidupannya. Ini bertentangan dengan ajaran Islam yang menyatakan bahwa Tuhanlah yang Maha menentukan, meski manusia mempunyai kuasa usaha.

Dengan demikian, perbedaan mendasar antara aliran humanistik dengan Islam terletak pada pandangannya terhadap manusia. Humanistik beranggapan over optimistik dalam memandang manusia sedang Islam memandang manusia dengan optimist proportional, yang berarti bahwa selain mempunyai kemampuan 
luhur manusia juga mempunyai keterbatasan sehingga selalu ada tempat kembali dalam hidupnya.

\section{Psikologi Islami Sebagai Alternatif}

Uraian diatas menunjukkan bahwa aliran psikologi dewasa ini mempunyai kelemahan mendasar sehingga jika digunakan untuk menjelaskan masalah yang muncul kemungkinan terjadi bias. Keadaan seperti ini tentu harus dicarikan alternatif yang bisa menggantikan kedudukannya, yaitu Psikologi Islami. Kenapa psikologi Islami dan bukan psikologi yang lain? Hal ini sangat tergantung pada siapa pengguna dari ilmu tersebut. Mungkin akan lahir psikologi-psikologi yang lain, Psikologi Kristiani, misalnya. Hal ini sah secara keilmuan. Hanya saja, Psikologi Islami lahir didasarkan atas kenyataan bahwa Islam mempunyai konsepkonsep tersendiri dan berbeda dari yang lainnya. Menurut Kuntowijaya, konsep ini bersumber dari al-Quran, al-Hadits, dan khasanah keilmuan Islam yang lain. ${ }^{12}$

Ada dua pendapat tentang pengertian dari Psikologi Islami itu sendiri. Pendapat pertama mengatakan bahwa psikologi Islami adalah suatu corak (aliran) psikologi yang dihasilkan dari filterisasi terhadap teori-teori psikologi modern, sementara pandangan kedua menyatakan bahwa psikologi Islami adalah suatu aliran psikologi yang dibangun atas dasar konsep-konsep yang ada dalam sumbersumber ajaran Islam.

Cara pertama, punya keuntungan yang sangat praktis dan bisa digunakan dalam waktu yang singkat, karena hanya dengan mengkritisi teori-teori yang ada (menambah, membuang, mencocokkan) dengan teori-teori yang bersumber dari ajaran Islam, maka jadilah konsep psikologi Islami. Kelemahannya, kemungkinan akan terjadi bias dalam proses pembentukan konsep-konsep yang baru.

Cara kedua, punya keuntungan dalam kematangan suatu konsep karena memang berawal dari sumber utama dari ajaran Islam. Caranya adalah dengan menghadirkan suatu konsep baru dari ajaran Islam kemudian melakukan penelitian ilmiah. Cara ini butuh waktu untuk segera menemukan konsep baru, padahal konsep tersebut sudah sangat urgen untuk segera ditampilkan. Karena itu, akhirnya diambil perpaduan antara keduanya, sehingga yang disebut psikologi Islami adalah suatu corak psikologi dalam pengertian pertama untuk jangka pendek, dan pengertian kedua kedua untuk jangka waktu panjang.

Untuk membangun sebuah Psikologi Islami sebagai sebuah disiplin keilmuan tentu masih banyak yang harus dilakukan dan diperjuangkan, karena adanya tantangan eksternal (para ahli psikologi yang bukan beragama Islam) dan internal (para ahli psikologi yang beragama Islam) yang belum tentu sepakat dengan faham ini. Namun, terlepas dari polemik diatas, penulis beranggapan bahwa psikologi Islami sangat mungkin bisa dimunculkan ke permukaan dengan catatan ada usaha dan komitmen dari para ahli psikologi dan ahli agama untuk terus mengembangkannya sehingga psikologi islami benar-benar lahir sebagai rahamatan lil'alamin. 


\section{Catatan Akhir.}

${ }^{1}$ Ziauddin Sardar, Masa Depan Islam, (terj), (Bandung: Pustaka Salman, 1986). Menurut Sardar gerakan Islamisasi ilmu yang tidak dilandasi dengan landasan yang kuat justru akan menimbulkan pada westernasisi, dan hal ini menjadi bertentangan dengan semangat gerakan Islamisasi ilmu yang sesungguhnya.

${ }^{2}$ Ismail R. Faruqi, 1982, Islamization of Knowledge, General Principles \& Workplan, (Virginia: IIIT, 1982), Alasan Faruqi sebenarnya lebih berorientasi pada alasan praktis karena kenyataan yang ada saat ini sudah sangat mendesak untuk segera dicarikan alterntif keilmuan sebagai akibat dari adanya kelemahan pada ilmu-ilmu modern dewasa ini.

${ }^{3}$ Jamaluddin Ancok, \& Nashori, F., Psikologi Islami, Solusi Islam atas Problem-problem Psikologi, (Yogyakarta: Pustaka Pelajar, 1994). xxi-xxii. Gerakan Islamisasi psikologi yang dilakukan oleh para ahli psikologi di Indonesia sudah banyak dilakukan baik berupa seminar, simposium, dan lain sebagainya, bahkan sudah dilaksanakan konggres pertama oleh Asosiasi Psikologi Islami (API). Asosiasi ini merupakan perkumpulan para ahli dan pemerhati terhadap perkembangan psikologi Islami.

4 Thomas Kuhn, The Structure of Scientific Revolution, (Chicago: The University of Chicago Press, 1970). Dalam penjelasannya lebih lanjut, Kuhn menyatakan bahwa suatu teori baru akan muncul ketika teori yang ada sudah tidak mampu memberikan penjelasan terhadap fenomena yang ada.

5 Kerlinger, Azaz-Azaz Penelitian Behavioral (terj), (Yogya, Gajah mada Press, 1995), 14-5. Dia menyebutkan bahwa ada empat fungsi dari teori yaitu untuk mendeskripsikan, menjelaskan, mengontrol, dan memprediksi terhadap suatu fenomena yang akan terjadi secara akurat dan ilmiah.

${ }^{6}$ Ketiga aliran tersebut, peratama adalah psikoanalisis yang penekanan kajiannya lebih berorientasi kepada alam ketidak-sadaran, kedua aliran behavioristik yang kajiannya berorientasi pada perilaku yang teramati, dan ketiga adalah aliran humanistik yang dianggap lebih manusiawi karena kajiannya terletak pada bagaimana potensi-potensi pada manusia teraktualisasikan.

${ }^{7}$ Nashori, Membangun Paradigma Psikologi Islami, (Yogyakarta: Sipress. 1994), 31.

8 Sigmund Freud adalah seorang Yahudi yang dianggap sebagai bapak pendiri psikoanalisis. Gagasan-gagasannya menjadi bahan perbincangan banyak ahli baik yang pro maupun yang kontra. Salah satu Pandangannya yang banyak dikritisi adalah pendapatnya terhadap agama yang cenderung negatif.

9 Ruth Benedict menemukan bahwa semangat kompetisi yang dianggap sebagai teori universal dalam psikologi ternyata tidak ditemukan pada suku Indian, bahkan yang ada adalah semangat untuk saling membantu.

10 Salah satu pandangan ekstrem kaum behavioris dikemukakan oleh Watson. Ia menyatakan kesanggupannya untuk menjadikan seorang anak sesuai dengan keinginannya. Dengan demikian seorang anak bisa diperlakukan sebagaimana layaknya sebuah mesin.

${ }^{11}$ Logotherapy, adalah suatu cabang aliran psikologi humanistik. Aliran ini didirikan oleh Viktor Frankl seorang Yahudi yang pernah selamat dari Camp maut kaum Nazi. Inti teori dari aliran ini adalah keinginan untuk hidup bermakna.

${ }^{12}$ Kuntowijoyo, Paradigma Islam, Interpretasi Untuk Aksi, (Bandung: Mizan, 1991), $327-331$.

\section{DAFTAR PUSTAKA}

Ancok, D., \& Nashori, F., 1994, Psikologi Islami, Solusi Islam atas Problemproblem Psikologi, Yogyakarta: Pustaka Pelajar 
Faruqi, I.R., 1982, Islamization of Knowledge, General Principles \& Workplan, Virginia: International Institute of Islamic Thought

Kuhn, T., 1970, The Structure of Scientific Revolution, Chicago: The University of Chicago Press

Kuntowijoyo, 1991, Paradigma Islam, Interpretasi Untuk Aksi, Bandung: Mizan Nashori, F., 1994, Membangun Paradigma Psikologi Islami, Yogyakarta: Sipress Sardar, Z., 1986, Masa Depan Islam, (terjemahan), Bandung: Pustaka Salman 